\section{Sebastian Porzuczek}

Uniwersytet Jagielloński

\title{
O pożytkach z gniewnych ekspresji bólu. Przywrócona podmiotowość \\ i perwersyjne pragnienie przynależności w kontekście opowiadań Thomasa Bernharda
}

\begin{abstract}
On the Benefits of Expressing Pain Through Anger. Restored Subjectivity and the Perverse Desire to Belong in Thomas Bernhard's Short Stories
\end{abstract}

The aim of this article is to present the relation between pain and anger in Thomas Bernhard's autobiographical stories: Der Atem. Eine Entscheidung and Die Kälte. Eine Isolation. The Austrian writer precisely reconstructs the social context of recognising disease and the status of suffering in institutional medicine. In this article, the tension between individual experience of pain and therapeutic procedures is analysed in the context of power and domination. However, the author pays special attention to the problem of subjective transformation of pain into anger (the logic of rebellion, agon).

Słowa kluczowe: Bernhard Thomas, ból, cierpienie, gniew, medycyna

Keywords: Bernhard Thomas, pain, suffering, anger, medicine 
Przerysować ból, aby uczynić go znośniejszym; z depresji cierpienia wznieść się w ,zuchwałą rozpacz” [...]; spiętrzać uczucie doznanej niesprawiedliwości na kształt góry, aby w gorzkim triumfie stanąć później na jej szczycie...

P. Sloterdijk, Gniew i czas

Ty jednak podążaj swoją drogą i na podobieństwo sceptycznego słońca oświetlaj ją promieniami zadumanej złości²

E. Cioran, Brewiarz zwyciężonych

[...] chory może zostać wyleczony tylko wówczas, gdy interweniują inni-z ich wiedzą, z ich materialnymi środkami, z ich litością, ponieważ chory może zostać wyleczony wyłącznie w obrębie społeczeństwa... ${ }^{3}$

M. Foucault, Narodziny kliniki

Nie będzie chyba nadużyciem stwierdzenie, że fenomen bólu zajmował szczególne miejsce w literackiej działalności Thomasa Bernharda. Owa problematyka - w szerszym kontekście procesu chorowania - ze szczególnym natężeniem ujawnia się w jego dwóch autobiograficznych opowiadaniach: Oddech. Wyzwolenie (Der Atem. Eine Entscheidung) oraz Chłód. Izolacja (Die Kälte. Eine Isolation). Z opowiadań austriackiego pisarza wyłania się theatrum choroby, w którym cierpiący jest rekwizytem, marionetką, kierowaną przez siły zewnętrzne znajdujące się poza sferą jego intencjonalności. Tak zarysowany kontekst stanowi punkt wyjścia do literackiego sondowania rzeczywistości choroby oraz podejmowania prób ekspresji bólu, w których Bernhard wykorzystuje afektywny potencjał gniewu: z agresywnej logiki konfrontacji czyni szczególny mechanizm obronny, przywracający podmiotowość cierpiącej jednostce.

\section{Wykluczenie a perwersyjna logika przynależności}

Prezentowane w prozie Bernharda sanatorium postrzegać można - odwołując się do pojęcia zaproponowanego przez Michela Foucaulta - jako przestrzeń heterotopijną, a konkretniej: nowoczesną heterotopię dewiacji ${ }^{4}$ (to m.in. miejsce przeznaczone dla przewlekle/terminalnie chorych, pacjentów zmagających się z chronicznym bólem). W tym kluczu teoretycznym wszechobecność

${ }^{1}$ P. Sloterdijk, Gniew i czas. Esej polityczno-psychologiczny, przeł. A. Żychliński, Warszawa 2011, s. 57.

2 E. Cioran, Brewiarz zwyciężonych, przeł. I. Kania, Kraków 2016, s. 89.

${ }_{3}$ M. Foucault, Narodziny kliniki, przeł. P. Pieniążek, Warszawa 1999, s. 116.

${ }^{4}$ Por. M. Foucault, Inne przestrzenie, przeł. A. Rejniak-Majewska, „Teksty Drugie” 2005, nr 6, s. 121. 
bólu uznać można za figurę dewiacji, czyli stan naruszenia powszechnie przyjętej/przeciętnej formy egzystencji - rozumianej także jako rodzaj społecznej homeostazy: równowagi w międzyludzkiej dystrybucji radosnych i przykrych doświadczeń oraz doznań. W heterotopijnej przestrzeni sanatorium rozchwianiu ulegają ogólnospołeczne reguły, zasady poprawnego zachowania, kategoryzacji praktyk dozwolonych i zakazanych, przesuniętych w sferę tabu, wypieranych jako obrzydliwe, abiektalne ${ }^{5}$ :

[...] kasłałem nawet bezwstydnie i bezczelnie przed siebie, obojętnie [...], przyłapywałem się na tak wielkim niedbalstwie, braku wychowania i nieprzyzwoitości, jakie przedtem robiły na mnie wrażenie absolutnie niedopuszczalnych i ohydnych ${ }^{6}$.

Sanatorium w opowiadaniach Bernharda przedstawiane jest konsekwentnie jako przestrzeń poddana ścisłym regulacjom (rytm praktyk medyczno-paliatywnych, izolacja mężczyzn od kobiet), procedurom kontroli chorych oraz przeniesionej ze świata zewnętrznego quasi-kastowej stratyfikacji, odwołującej się zwykle do ekonomicznej wyższości, choć nierzadko wynikającej także z biegłości doświadczonych pacjentów w sztuce chorowania ${ }^{7}$.

Wobec nowego pacjenta - jako obcego, ponieważ jeszcze niezdiagnozowanego - chorzy pozostawali nieufni, warunkiem przyjęcia do „sprzysiężenia” cierpiących była bowiem medycznie potwierdzona śmiertelna przypadłość:

Ale ciągle pozostawałem negatywny. [...] Czyż nie miałem obowiązku stać się taki jak cała reszta? Pozytywny? Po pięciu tygodniach doszło do tego, orzeczenie brzmiało: pozytywny. Nagle stałem się w pełni członkiem wspólnoty ${ }^{8}$.

W kolektywnym poczuciu zadowolenia z diagnozy (rozpoznania prątkowania jako znaku choroby) także bohater przyjmuje informację o zidentyfikowaniu dolegliwości jako radosny wyraz uznania przez wspólnotę chorych, włączenia go w ramy grupowych obyczajów/rytuałów (np. rywalizacji w odpluwaniu flegmy), w czym rozpoznać można perwersyjny charakter statusu pacjenta: „Perwersyjność (niem. die Perversität) tej sytuacji nie docierała

${ }^{5}$ Odwołuję się tu do rozważań Julii Kristevej o abiekcie i wstręcie, dla których relewantny był aspekt etyczny: „osądu i afektu” (por. J. Kristeva, Potęga obrzydzenia. Esej o wstręcie, przeł. M. Falski, Kraków 2007, s. 15). Wątki te szerzej omawiała Anna Łebkowska (por. eadem, Jak ucieleśnić ciało: o jednym z dylematów somatopoetyki, „Teksty Drugie" 2011, nr 4, s. 23).

${ }_{6}$ T. Bernhard, Chłód. Izolacja [w:] idem, Autobiografie, przeł. S. Lisiecka, Wołowiec 2011, s. 276.

${ }^{7}$ Bernhard uwydatnia ów niemal narcystyczny aspekt chorowania, który realizuje się poprzez wnikliwe studiowanie swoich dolegliwości, skrupulatne badanie widocznych na ciele znaków postępującej choroby.

8 T. Bernhard, Chłód. Izolacja..., s. 275. 
wcale do mojej świadomości”’ Zgodnie ze słownikową etymologią ,perwersja” pochodzi od łac. perversio, definiowanego jako „obrócenie w niewłaściwym kierunku; przekręcenie; zepsucie"10, a więc odwrócenie naturalnego porządku, w którym to, co dewiacyjne, abiektalne, wartościowane jest dodatnio - jako stan pożądany. Pragnienie bycia pozytywnym sankcjonuje grupowe tendencje inkluzyjne, stanowi podstawowy warunek przynależności i adaptacji, ale uwydatnia też zaburzenie aksjologicznego porządku świata. Puszczony w ruch ,perwersyjny młyn choroby” stanowi przewrotne (die Perversität to także „przewrotność”) uobecnienie dwóch sprzecznych sił (intencji): pragnienia uleczenia i potrzeby uzyskania akceptacji ze strony wspólnoty chorych (alternatywą dla niej jest bowiem absolutna alienacja: status jednostki rzuconej „w podwójną samotność”" ${ }^{11}$ ). W tej ostatniej dostrzec można także pokusę śmierci jako natychmiastowej ulgi w cierpieniu.

Bernhard portretuje pacjentów wypchniętych na margines społeczeństwa, trwających na granicy wegetacji, wyzutych z wszelkiej teleologii, pozbawionych ideowego punktu oparcia, maksymalnie skoncentrowanych na swoim ciele i jego postępującej destrukcji. Sanatorium izolowało chorych w sposób radykalny, skazywało na absolutne wykluczenie (fizyczne i symboliczne):

Tak zwany zdrowy świat bał się panicznie słów choroba płuc, terminu gruźlica, nie mówiąc już o terminie otwarta gruźlica płuc, boi się ich jeszcze dzisiaj. Niczego nie bał się bardziej. [...] Z chorym na płuca nie obcowano, schodzono mu z drogi. [...] Nawet rodziny, nie wyłączając mojej, izolowały, ba, potępiały swoich chorych na płuca $^{12}$.

Procedura poddania chorego izolacji stanowiła ingerencję w sferę jego najintymniejszych (rodzinnych) stosunków - wykluczała go de facto z każdej relacji międzyludzkiej, dla której podstawowym punktem odniesienia nie była choroba. Znamienne w tym kontekście są znaki ostrzegawcze/zakazy wypisane na tablicach, ustawionych na granicy obszaru przeznaczonego dla chorych (narrator rejestruje je zarówno na terenie kompleksu szpitalnego, jak i sanatorium): Stop! Teren zakładu. Wstęp wzbroniony! Stop! Przejście zabronione! Owe słowa-performatywy, uwydatnione wykrzyknikami, mają nie tylko charakter urzędowo-informacyjnego komunikatu (który można zaakceptować bądź naruszyć na własną odpowiedzialność), lecz także stanowią ostrzeżenie-groźbę: stanowczy głos instytucji, dyscyplinujący osobniki

9 Ibidem, s. 275.

${ }_{10}$ W. Kopaliński, Perwersja [w:] Stownik wyrazów obcych i zwrotów obcojęzycznych, Warszawa 2007, s. 438.

11 T. Bernhard, Chłód. Izolacja..., s. 301.

12 Ibidem, s. 286-287. 
groźne (chorych dysponujących mocą zarażania ${ }^{13}$ ). Foucault trafnie zwracał uwagę na niejednoznaczność relacji przestrzeni heterotopijnych ze światem zewnętrznym: „Heterotopie zawsze zakładają system otwarcia i zamknięcia, który jednocześnie izoluje je i czyni przepuszczalnymi”" ${ }^{14}$, co uwydatnia problem sprzężenia terapeutycznej izolacji chorego $\mathrm{z}$ ujawniającymi się $\mathrm{w}$ przestrzeni mu przeznaczonej wpływami świata zewnętrznego: symboliczną ramą dla praktyki medycznej stają się tu społeczne procedury wykluczania innego.

\section{Widok bólu: ciało-sarkos i anestetyki}

Z Oddechu i Chłodu wyłania się wiele naturalistycznych obrazów somy. Choroba i proces medycznej terapii odciskają swoje ślady na fizjonomii cierpiącego, czyniąc ciało przerażająco obcym. Wbrew zgoła nietzscheańskim interpretacjom $^{15}$, które formułuje dziadek bohatera, „dusza i umysł” nie potrafią zapanować nad ciałem, fizjologiczna obecność bólu nie podlega dyskursywnej, intelektualnej neutralizacji. Chory - regularnie poddawany praktykom medycznym (również eksperymentalnym), które zaburzają zwykły rytm egzystencji - trwa w przekonaniu o utracie kontroli nad swoim ciałem, w nieustannym lęku o życie.

Nieznośna bliskość śmierci każe wątpić nie tylko w marzenia o wyleczeniu i lepszej przyszłości; fiaskiem kończy się również próba odnalezienia oparcia w sferze sacrum. Eschatologia nie przynosi choremu ulgi, lecz jawi się jako znak religijnej obojętności, neutralizacji bólu w ramach fasadowego i komicznego rytuału. Bernhard z gwałtowną ironią odnosi się do działalności kapelana, który machinalnie, bezwiednie namaszcza-naznacza kolejnych kandydatów do śmierci:

Wystarczyło tylko nacisnąć dwa boczne guziczki, a kuferek otwierał się i wieko wystrzelało do góry. W tej samej chwili ustawiały się automatycznie w pozycji pionowej dwa świeczniki ze świecami i srebrny krucyfiks. Siostry zapalały świece i duchowny zaczynał swój obrządek ${ }^{16}$.

${ }^{13}$ Susan Sontag ujmowała kulturowy wizerunek chorego jako jednostki potencjalnie groźnej, niebezpiecznej, z którą kontakt, ,jest nieuchronnie odczuwany jako przekroczenie pewnej granicy, a nawet złamanie tabu" (S. Sontag, Choroba jako metafora. AIDS i jego metafory, przeł. J. Anders, Warszawa 1999, s. 10).

${ }_{14}$ M. Foucault, Inne przestrzenie..., s. 123.

${ }^{15} \mathrm{Na}$ temat Nietzscheańskiej interpretacji bólu, który - w ramach postawy estetycznej - ma charakter afirmatywnie dyscyplinujący (hartujący ducha) zob. Ł. Musiał, Samotność Zaratustry (Friedrich Nietzsche) [w:] idem, O bólu, Poznań 2016, s. 36-58.

16 T. Bernhard, Oddech. Wyzwolenie [w:] idem, Autobiografie..., s. 208. 
Widok fałszywie rytualnej (,perwersyjny, katolicki, szmirowaty spektakl" "17) figuracji męki Chrystusa, ujętej w ramy porządku zbawienia, nie prowadzi do duchowej iluminacji, lecz uwydatnia nieprzystawalność sakralnej praktyki do fizjologicznej obecności bólu ciała. Naturalizm Bernharda, przesycony czarnym humorem ${ }^{18}$, stanowi gwałtowny sprzeciw wobec kulturowego zobojętnienia na cielesne cierpienie, które objawia się w postaci chrześcijańskiego odrzucenia tego, co immanentnie związane z somatycznością. Toteż wyłaniające się z Oddechu i Chłodu obrazy ciał paskudnych, podłych, wydzielających odór zgnilizny, wewnętrznego rozpadu - „Życie i istnienie odrzuciły tę kupę zgniłego mięsa (niem. faulen Haufen Fleisches) w kąt, który był ostatnim zakątkiem dla tego życia i istnienia, po czym się ulotniły"19 - można odczytywać jako radykalną polemikę z tradycyjnie chrześcijańską (z ducha Orygenesa) wykładnią ciała w ramach antynomii: soma (czyste, niefizjologiczne, powołane do odkupienia ciało) i sarx (ciało pożądające, siedlisko popędów, naczynie grzechu, wstrętne mięso ${ }^{20}$. Cierpiące ciało nie jest w prozie Bernharda przeznaczone do uświęcającego odkupienia; ból jako to, co semiotyczne, nie poddaje się opresyjnym i nieadekwatnym praktykom sakralnej symbolizacji, które realizują się poprzez automatyczne, puste gesty, obojętne i wolne od emocjonalnego zaangażowania czynności. Sakralna czystość stoi w sprzeczności z brudem (fizjologia) ciała i ta niewspółmierność budzi w chorym narratorze wściekłość, wstręt, prowadzi do błazeńskiej kpiny, profanacji sakramentu przez abiektalny rytuał à rebours ${ }^{21}$, w którym butelka do odpluwania flegmy staje się monstrancją, a parodystycznym ekwiwalentem przyjmowania hostii (uświęconego, symbolicznego ciała Chrystusa) okazuje się nieustanny proces wyrzucania z siebie plwociny (abiektu).

Choć sceny z Oddechu i Chłodu nasycone są doznaniami sensualnymi, to łatwo zauważyć zmianę w sposobie percypowania rzeczywistości przez chory podmiot - początkowe wrażenie drastyczności widoku cudzego bólu zanika bowiem w dwójnasób: poprzez chemiczną analgezję (stosowanie silnych środków znieczulających) oraz w wyniku nagromadzenia obrazów bólu, które

17 Ibidem, s. 209.

18 A. Lipszyc, Odpluwanie światem, „Książki w Tygodniku. Dodatek do »Tygodnika Powszechnego«" 2011, nr 5, s. 10.

19 T. Bernhard, Chłód. Izolacja..., s. 330 (wyróżn. - S.P.).

${ }^{20}$ Orygenes, Komentarz do Listu św. Pawta do Rzymian, przeł. i oprac. S. Kalinkowski, wstęp E. Stanula, Warszawa 1993.

${ }^{21}$ Adam Lipszyc podkreśla aspekt parodii wymierzonej we wspólnotę religijną (idem, W tyl zwrot na Reichenhallerstrasse, „Literatura na Świecie” 2012, nr 7-8, s. 422). 
działa jak wizualny anestetyk - akumulacja bodźców przytępia wrażliwośćc ${ }^{2}$. Narrator wielokrotnie podejmuje problem intensywnego działania medykamentów na jego percepcję:

[...] moja zdolność postrzegania obniżona była już do minimum za przyczyną licznych zastrzyków z penicyliny i kamfory [...] na skutek zaaplikowanych mi tymczasem lekarstw utraciłem wszelką siłę woli [...], gdy ustąpiły bóle, wyzbyłem się strachu i cały byłem jedynie spokojem i zobojętnieniem ${ }^{23}$.

[...] [po zabiegu - S.P.] obrazy w mojej głowie ulegały rozbiciu ${ }^{24}$.

Zaburzenie zdolności postrzegania wprawia chorego w stan zagubienia, permanentnego poczucia dezorientacji (w czasie i przestrzeni). $\mathrm{Z}$ narracji w Oddechu i Chłodzie wyłania się czas chorowania pozbawiony wyraźnych granic, punktów zwrotnych: „[...] straciłem poczucie czasu”"25. Niejednoznaczność czasu terapii uwydatnia Bernhard stosowaniem kursyw, które zwykle funkcjonują w jego prozie jako znaki obcości - w tym przypadku czymś obcym, abstrakcyjnym, jest właśnie czas: ,[...] przez kilka dni leżałem w pokoju dziadka”26, „Nie chcę umrzeć, myślę. Nie teraz”27. Skutkiem chorowania - oraz przypisanych mu procedur terapeutycznych - jest podmiot bierny, otępiały, cierpliwie znoszący kolejne etapy kuracji, obojętnie poddający się poszczególnym zabiegom, co bodaj najbardziej wyrazistą realizację uzyskało w scenie zabiegu chirurgicznego. Narracja prowadzona w czasie teraźniejszym (choć na koniec zaznacza się dystans czasowy - to re-konstrukcja zdarzeń) intensyfikuje poczucie trwania operacji, ujawniania się kolejnych bodźców, które operowany przyjmuje niemal zupełnie bezwiednie. Bohater rejestruje kolejne zdarzenia, uświadamiając sobie szczególny stan wewnętrznej izolacji świadomości (doświadczenia bliskiego martwocie własnego ciała) ${ }^{28}$, zabu-

${ }^{22}$ Narrator wielokrotnie wspomina o stłumieniu wrażliwości, ,połowiczności” (przytłumieniu) chorych, ich niezdolności do odczuwania intensywnych doznań estetycznych, ideowego zaangażowania. Funkcjonalne wydaje się w tym kontekście pojęcie anestetyzacji, twórczo analizowanej m.in. przez Odona Marquarda czy Wolfganga Welscha: „»Anestetyka« - według Welscha - [...] tematyzuje brak doznań, w sensie utraty, ograniczenia albo wykluczenia zdolności doznawania, i to na wszystkich poziomach: od fizycznego otępienia po duchową ślepotę" (W. Welsch, Estetyka i anestetyka, przeł. M. Łukasiewicz [w:] Postmodernizm. Antologia przekładów, red. R. Nycz, Kraków 1998, s. 522).

23 T. Bernhard, Oddech. Wyzwolenie..., s. 194-195.

${ }^{24}$ Ibidem, s. 233.

${ }^{25}$ Ibidem, s. 196.

26 Ibidem, s. 196.

27 Ibidem, s. 197. Heterotopie (heterochronie) wykazują zwykle szczególny stosunek do czasu, wyrażający się poprzez absolutne zerwanie podmiotów-mieszkańców heterotopii „ze swoim tradycyjnym czasem” (M. Foucault, Inne przestrzenie..., s. 123).

28 E. Jünger, $O$ bólu, przeł. J. Prokopiuk, „Literatura na Świecie” 1986, nr 9, s. 226. 
rzenia relacji między percypowanymi działaniami i (nie)rejestrowanymi cielesnymi doznaniami. Procedura medyczna dokonuje się machinalnie, niemal automatycznie; czynności, którym poddawany jest chory, są „,bardzo brutalne, ale bezbolesne" 29 , uświadamiane jedynie częściowo (pojawia się tu znamienny gest zasłaniania i odsłaniania twarzy). Scena dramatycznego zbliżenia się do śmierci postrzegana jest jako seria dynamicznych, niejasnych zdarzeń niezrozumiałe „coś”, co się stało, to element medycznej wiedzy, do której pacjent nie ma dostępu. Bernhard drobiazgowo rekonstruuje poszczególne etapy inwazyjnych zabiegów medycznych, by uwydatnić każdy ruch, pojedynczy akt agresji wobec ciała. Poprzez analizę dyskursu klinicznego Foucault rozpoznał immanentny dla praktyk medycznych aspekt dramatyzacji cierpienia (czynienia z bólu widowiska w ramach klinicznego spojrzenia), dla którego zasadniczym celem nie jest uśmierzenie bólu, lecz ujawnienie jego obecności, by wyczytać w uprzedmiotowionym ciele przyczynę, źródło doznania ${ }^{30}$. W porządku metodologicznie ukonstytuowanych procedur działania pozostaje obecny „mit czystego Spojrzenia, które stałoby się czystym Językiem”31, iluzja bezpośredniości poznania: zdobycia wiedzy (to, co wypowiedziane), którą sfunkcjonalizować można w ramach nauki (to, co nauczane). Cierpiące ciało chorego staje się tu polem działania sił zewnętrznych, które - w sposób inwazyjny - usiłują wydobyć prawdę bólu w ramach paradygmatu widziećwiedzieć: prawda o cierpieniu i chorobie wyłania się w porządku dyskursu medykalizującego, a więc tego, co możliwe do wypowiedzenia/uchwycenia w języku medycyny ${ }^{32}$. Praktyka terapeutyczna immanentnie związana jest z aktami przemocy wobec ciała - zdeformowanego, oszpeconego, wytrąconego $\mathrm{z}$ równowagi (stosowany w leczeniu gruźlicy pas odbierał bohaterowi apetyt) w wyniku działania choroby i medykamentów oraz inwazyjnych zabiegów medycznych. To ciało-przedmiot ${ }^{33}$, które $\mathrm{z}$ uporem i bezwzględnością poddawane było kolejnym operacjom.

Innego rodzaju przytłumienie wrażliwości na widok cierpienia dokonuje się w wyniku nagromadzenia obrazów bólu. Początkowy szok (reakcja na widok nie-do-zniesienia), związany z widokiem chorych w stanie terminalnym, ustępuje miejsca codziennej rutynie - narrator przechodzi na pozycję zdystan-

29 T. Bernhard, Chłód. Izolacja..., s. 323.

${ }^{30}$ Więcej nawet: Foucault identyfikuje w klinicznej metodzie anatomopatologicznej jako de facto pewnego rodzaju interpretacji (uprzedmiotowionego) ciała - możliwość zarówno symptomatologicznego odczytania tajemnicy dolegliwości (ciała) z wnętrza (organów), jak i wpisania w cierpiące ciało swojej (zewnętrznej/dyskursywnej) interpretacji. Zob. W. Mackiewicz, Ciało i polityczność. Koncepcja cielesności w filozofii Michela Foucaulta, Kraków 2018, s. 168.

${ }_{31}$ M. Foucault, Narodziny kliniki..., s. 150.

32 Ibidem, s. 128. Por. także S. Sontag, Choroba jako metafora. AIDS i jego metafory..., s. 122.

${ }^{33}$ E. Jünger, op.cit., s. 226. 
sowanego świadka. Wykorzystanie figury obserwatora, czy też obserwatora uczestniczącego, pozwala Bernhardowi uwydatnić proces przemiany dokonującej się w chorym, który zdarzenia wywołujące niegdyś gwałtowne przerażenie przyjmuje w sposób zdystansowany, wyzuty z emocjonalności: chory „we własne cierpienia, bóle i obserwacje swojej własnej chorej osoby musi wkalkulować również cierpienia, bóle i obserwacje tych wszystkich, z którymi przyszło mu dzielić pokój [... $]^{\prime 34}$. Obserwacja inicjuje rozumowe/racjonalne procedury analizy: postrzegania (wzrok implikuje dystans) i rozumienia (badania, studiowania przypadków): ,[...] odkryłem na nowo przyjemność, jaką daje myślenie, a zatem rozbiór, roztrząsanie i rozważanie obserwowanych rzeczy"35. Próby zdystansowania się, czyli neutralizacji siły obrazów, stały się dla bohatera konieczne jako mechanizm obronny: „Takiego dystansu potrzebowałem po prostu do życia, tylko tak mogłem ocalić swoje istnienie"36. Wyostrzona percepcja chorego, pochwytując obrazy cierpienia i śmierci konsekwentnie odsuwane sprzed oczu „zdrowego” społeczeństwa w instytucjonalnych ramach szpitalno-sanatoryjnej „fabryki śmierci” - umacnia w nim bowiem poczucie niesprawiedliwości; krzywdy, która staje się wreszcie zapalnikiem podmiotowego buntu.

\section{Odzyskiwanie podmiotowości i logika konfrontacji}

Proces odzyskiwania podmiotowości (nadawania chorobie idiomatycznej sygnatury) realizuje się u Bernharda w ramach logiki konfrontacji - buntu wobec dyskursu medycznego i sanatoryjnego reżimu. Motta poprzedzające omawiane opowiadania (z Novalisa: „Każdą chorobę można nazwać chorobą duszy”, i z Pascala ${ }^{37}$ : „Ponieważ ludzie nie byli zdolni przezwyciężyć śmierci, nędzy i niewiedzy, uzgodnili dla własnego szczęścia, że przestaną o tym myśleć”) odsyłają do groźby, ale i pokusy popadnięcia w inercję, poddania się logice postępującej choroby w wyniku gwałtownego nagromadzenia negatywnych, destrukcyjnych doznań (bólu jako doznania psychofizycznego, którego skutkiem jest zarówno uwiąd ciała, jak i osłabienie woli ${ }^{38}$ ) i zdarzeń (niepoddających się mechanizmowi przepracowania):

34 T. Bernhard, Oddech. Wyzwolenie..., s. 251.

${ }^{35}$ Ibidem, s. 245.

36 T. Bernhard, Chłód. Izolacja..., s. 291.

37 Według Pascala ból to cielesne doznanie, które nieuchronnie poddajemy interpretacji, refleksji, intelektualnej obróbce (zob. D.B. Morris, The Culture of Pain, Berkeley 1993, s. 44).

${ }^{38}$ To konstatacja z ducha Schopenhauerowska. Por. S. Sontag, Choroba jako metafora. AIDS i jego metafory..., s. 47. 
[...] należałem do społeczności umierającej, odchodzącej. Zagłębiłem się w tej nagle wcale dla mnie nie absurdalnej myśli i doszedłem do wniosku: tutaj chcę być! Bo gdzież indziej? I poddałem się chronologii umierania i piekła ${ }^{39}$.

Na przekór jednak eskapistycznym tendencjom, uobecnionym w postawie biernej, Bernhard uprzywilejowuje - aktywizującą zdolności podmiotowe postawę sprzeciwu, niezgody na aktualny stan egzystencji. Toteż konfrontacja z bólem zyskać powinna charakter indywidualnego gestu, osobistych zmagań poza porządkiem medycznych procedur leczenia, czyli oddziaływania sił zewnętrznych: „Chory sam musi wziąć swoje cierpienie w ręce, wziąć je sobie na głowę przeciw lekarzom, takie poczyniłem doświadczenie"40. Początkiem buntowniczych prób bohatera jest świadome naruszenie regulaminu sanatorium: piesze wycieczki poza granice przeznaczonego pacjentom obszaru to namacalny znak mentalnego i cielesnego wyzwalania się z opresyjnego, petryfikującego zdolności podmiotowe systemu. Fizyczne przekroczenie granicy odsyła do aktu naruszenia instytucjonalnej normy - pomimo ryzyka kary, natychmiastowego usunięcia z placówki medycznej - co okazuje się działaniem ożywczym:

[...] miałem niezłomny zamiar codziennie łamać regulamin sanatorium, w absolutnej tajemnicy i z absolutną zręcznością codziennie zachodzić do wsi, musiałem łamać prawa Grafenhofu, aby poprawić stan swojego zdrowia. [...] Musiałem starać się stąd wyjść, i to szybko. W tym celu jednak trzeba mi było siły do łamania rządzących tu praw, rządzących absolutnie, i do życia zgodnie z własnymi prawami, coraz bardziej zgodnie z własnymi, a coraz mniej według praw mi narzuconych ${ }^{41}$.

Nieskuteczna próba adaptacji w środowisku sanatoryjnym okazała się dla narratora czynnikiem przywracającym siły witalne, pobudzającym pragnienie indywidualnego/samodzielnego istnienia, co ujawnia się w skłonności do uwydatniania swojego idiomu w tekście:

39 T. Bernhard, Chłód. Izolacja..., s. 281.

${ }^{40}$ Ibidem, s. 280. Przeciw lekarzom immanentnie związanym ze sprawowaniem władzy nad życiem. Jak powiada Peter Sloterdijk: ,[...] tylko sami możemy pomóc sobie w walce przeciwko działaniom lekarza-pana" (idem, Krytyka cynicznego rozumu, przeł. P. Dehnel, Wrocław 2008, s. 298).

${ }^{41}$ T. Bernhard, Chłód. Izolacja..., s. 343 (kurs. oryg; wyróżn. S.P.). 
Ja musiałem kierować lekarzami i ich pomocnikami, nie odwrotnie [...]. Ja decydowałem, ile mam otrzymywać streptomycyny, nie lekarze, pozwalałem im jednak wierzyć, że to oni o tym decydują [...], chociaż od tej pory działo się tylko to, co ja zdecydowałem $[\ldots]^{42}$.

To oni byli powaleni chorobą, nie ja, to oni byli skazani na śmierć, nie ja. Naraz uwierzyłem, że mam prawo zdystansować się wobec nich ${ }^{43}$.

Proces przywracania ,ja" realizuje się w ramach introspekcji, refleksji tożsamościowych, poszukiwania przyczyn aktualnej sytuacji egzystencjalnej, a praktyki te - nastawione na przywrócenie egzystencji prywatnego, intymnego wymiaru - trzeba uznać za szczególnie wartościowe. Wyzwolenie się $\mathrm{z}$ ciasnych ram procesu terapii w sanatorium, powzięcie emancypacyjnych prób $^{44}$ skonfrontowania się, także dyskursywnego, z bólem i chorobą, prowadzi chorego do podjęcia decyzji o opuszczeniu Grafenhofu na własną odpowiedzialność, podjęcia ryzyka bycia w świecie, ponownego zakotwiczenia się w rzeczywistości ${ }^{45}$. Indywidualna ekspresja afektu poprzez gniew, ujawniająca się w skłonności bohatera do agresywnej diatryby i dyskursywnej polemiki (z porządkiem religijnym, praktyką medyczną czy aktualną formą ładu społecznego), inicjuje pragnienie radykalnej podmiotowej zmiany egzystencjalnej, dla której sygnałem jest zawołanie: „Precz od lekarzy, z dala od Grafenhofu!"46.

\section{Obecność bólu i ekspresje gniewu}

W szpitalno-sanatoryjnych opowiadaniach Bernharda $\mathrm{z}$ doświadczeniami artystycznymi związane są epizody nadziei, momenty ulgi, w których chorowanie przesunięte zostaje na drugi plan. Muzyka wyznacza kontekst dla kształtujących się relacji (z kapelmistrzem i organistką z pobliskiego kościoła) i pierwszych buntowniczych, ożywczych peregrynacji poza teren sanatorium (bohater regularnie ćwiczy śpiew w pobliskim kościele). Muzyka jako pasja

42 Ibidem, s. 344.

43 Ibidem, s. 285.

${ }^{44}$ Można również w ogólniejszym ujęciu zidentyfikować emancypacyjny wymiar twórczości Bernharda, na co zwracał uwagę Paweł Jasnowski (por. idem, Świat jako kloaka i udawanie sensu. Paliatywy w świecie prozy Thomasa Bernharda, „Teksty Drugie” 2017, nr 2, s. 375-398).

${ }^{45}$ Bohater abonuje „Timesa”, czyli podejmuje próbę przywrócenia światowości (szerszego horyzontu) swojej egzystencji.

46 T. Bernhard, Chłód. Izolacja..., s. 349. 
oraz figura afirmacji, ekspresji, witalności ${ }^{47}$ przywraca choremu prywatność, której pozbawiony był w porządku masowych, instytucjonalnych procedur terapii. Podobnie lektura dzieł Verlaine'a, Trakla, Baudelaire'a, Dostojewskiego czy Sterne'a staje się tu doznaniem artystycznym o intymnym, ściśle psychofizycznym charakterze ${ }^{48}$. To, co literackie, wiąże się ponadto z możliwością poszerzania horyzontu własnych doświadczeń, co uznać trzeba za ożywcze W perspektywie inercyjnej monotonii rzeczywistości chorego. W narracjach Bernharda literatura okazuje się katalizatorem autoterapeutycznych działań, przywracających choremu podmiotowi kontrolę nad jego egzystencją:

[...] lektura może podać matematyczne rozwiązanie życia [...]. Dzięki czytaniu przekraczałem otchłanie, i tutaj ziejące o każdej dobie otworem, znajdując w lekturach ratunek przed stanami psychicznego rozbicia ${ }^{49}$.

[...] literatura poraziła mnie, abym mógł wyjść stąd jako bohater ${ }^{50}$.

Na przekór bezładnym, dynamicznym zmianom losu chorego - w ramach trajektorii oddziałujących sił zewnętrznych - immanentna dla literatury technika strukturyzacji i stabilizacji egzystencji przez narrację okazuje się istotnym elementem $\mathrm{w}$ procesie scalania rozbitej egzystencji chorego:

Jak więc to było naprawdę, pytałem, chronologicznie? I rozpakowywałem znowu wszystko, co było zapakowane, dobrze związane, powoli, miałem wszakże teraz potrzebny mi spokój, a kiedy wszystko już rozpakowałem, wojnę i jej konsekwencje, chorobę dziadka, śmierć dziadka, moją chorobę, chorobę matki, rozpacz wszystkich moich bliskich, ich przygnębiające warunki życia, istnienia pozbawione jakichkolwiek perspektyw, zapakowałem z powrotem to wszystko i związałem. Ale nie mogłem odłożyć tej związanej paczki, znowu musiałem zabrać ją ze sobą ${ }^{51}$.

47 „Wielotygodniowe śpiewanie [...] na tyle polepszyło mój stan ogólny, że pozwoliło mi uwierzyć w ozdrowienie za przyczyną muzyki [...]" (T. Bernhard, Chłód. Izolacja..., s. 347).

${ }^{48}$ Chory doświadcza sztuki w aspekcie psychofizycznym również w zupełnie prozaicznym sensie. Lektura Czterdziestu dni Musa Dah Franza Werfla okazuje się trudna nie tylko ze względu na treść, lecz także z powodu fizycznego ciężaru książki, którą trudno osłabionemu czytelnikowi utrzymać w rękach. Literatura działać może również jako bodziec dla woli (ducha), inicjować pragnienie egzystencjalnej zmiany (bohater zachwycony lekturą Biesów pragnie opuścić sanatorium, by „dotrzeć do następnych Biesów” - ibidem, s. 346) bądź wyznaczać przestrzeń afektywnego zbliżenia się w bólu (narrator, żegnając się ze śmiertelnie chorą matką - gdy zwykły język wydaje mu się komicznie nieadekwatny recytuje jej swoje wiersze, które stają się katalizatorem emocjonalnej reakcji).

49 T. Bernhard, Oddech. Wyzwolenie..., s. 264.

${ }^{50}$ Ibidem, s. 345.

${ }^{51}$ T. Bernhard, Chłód. Izolacja..., s. 302. 
W narracji wielokrotnie zaznacza się dystans czasowy; temporalna niekompatybilność opowieści uwydatnia się poprzez skontrastowanie narracji w rozwleczonym czasie teraźniejszym (performatywnie uobecniającym nieustanną tymczasowość chorego oraz obecność bólu, czyli doznania zawsze rejestrowanego jako aktualnie trwające ${ }^{52}$ ) z pojedynczymi znakami-sygnałami zdystansowanej pozycji narratora: „Notuję tutaj to, co zachodziło w umyśle młodzika, jakim wówczas byłem, nic więcej. Później wszystko mogło ukazać się w innym świetle, ale nie wtedy" ${ }^{53}$. Dystans czasowy, zaznaczany w tekście, wyznacza ramy opowieści - poprzez pracę pamięci ${ }^{54}$ i budowanie narracji jako próby sformułowania linearnej, strukturalnie uporządkowanej historii o własnym życiu (by ocalić „moją własną tożsamość, moją własną brutalność, mój własny gust" $\left.{ }^{\prime 5}\right)$. Narrator stara się wykreować fikcjonalny ekwiwalent rzeczywistej egzystencji ${ }^{56}$, której z powodu choroby nie potrafi kontrolować $\left(,[\ldots]\right.$ istniałem tylko wtedy, kiedy pisałem" $\left.{ }^{\prime 57}\right)$.

Jako że ów akt twórczy ma dla chorego szczególną, prywatną wartość, pytania o prawdziwość relacji tracą na znaczeniu: narrator stwierdza, że snuje opowieść o „zdarzeniach i wydarzeniach spisywanych [...] z intencją zachowania prawdy i jasności"'58 , by później - ostentacyjnie oddając hołd subiektywizmowi - stwierdzić:

Prawda zawsze jest omyłką, chociaż jest prawdą w stu procentach, każda omyłka nie jest niczym innym jak prawdą [...]. Mechanizm ten utrzymuje mnie przy życiu, czyni mnie do niego zdolnym. [...] Absurdalność to jedyna możliwa droga ${ }^{59}$.

52 Jak powiada Emil Cioran: „ból jako taki jest zawsze aktualny, teraźniejszy” (idem, Zeszyty 1957-1972, przeł. I. Kania, Warszawa 2016, s. 241).

53 T. Bernhard, Oddech. Wyzwolenie..., s. 223.

${ }^{54}$ Por. ,[...] mogłem wywoływać w sobie wspomnienie i sprawdzać je do woli" (T. Bernhard, Chłód. Izolacja..., s. 306). Agata Wittchen-Barełkowska definiuje pracę pamięci jako performatywne od-tworzenie (retrospektywne uobecnienie), „w którym przeszłość wystawiona zostaje na pokaz, odegrana raz jeszcze, a przez to ulega przemianom i deformacjom, pozostając w nieustannym, twórczym ruchu" (A. Wittchen-Barełkowska, Kategoria teatralności w dziele Thomasa Bernharda, Poznań 2014, s. 122).

${ }_{55}$ T. Bernhard, Chłód. Izolacja..., s. 345.

${ }^{56}$ Niejako w ramach logiki kupieckiej wymiany (nawiązując do zawodowego wykształcenia narratora). Rozpoznana tu rola narracji w procesie od-twarzania/zachowywania jednostkowej tożsamości, zakorzeniona jest w diachronicznym modelu kultury, który Roma Sendyka nazywa „kulturą ja”: „Narratywizacja siebie staje się koniecznym warunkiem nadawania sensu egzystencji, a nawet podstawą do budowania postaw etycznych: tylko bowiem scalone życie może nabrać etycznego charakteru" (R. Sendyka, Od kultury ja do kultury siebie. O zwrotnych formach w projektach tożsamościowych, Kraków 2015, s. 385).

${ }^{57}$ T. Bernhard, Chłód. Izolacja..., s. 287.

${ }^{58}$ Idem, Oddech. Wyzwolenie..., s. 191.

${ }^{59}$ Idem, Chłód. Izolacja..., s. 306. 
Prawdziwość (realność) - ewokowana poprzez „okruchy” prawdy, „luki i błędy”, „przybliżenia i próby” ${ }^{60}$, szereg "strzępków wspomnień” ${ }^{\circ 1}$ - jest jedynie fingowanym efektem mechanizmów urealnienia (nieprzypadkowo Bernhard wprowadza do swej narracji terminologię medyczną), funkcjonalnym dla chorego o tyle, o ile pozwala mu zachować wartość prywatnej opowieści, której wiarygodność opiera się na autonomii jego przeżyć:

Tego rodzaju zapiski trzeba czynić w każdym przypadku, zawsze oczywiście biorąc pod uwagę fakt, że stosunek do nich będzie wrogi [...]. Można dowieść piszącemu, zatem również tym zapiskom, iż posiadają luki, a nawet błędy, nigdy jednak nie dowiedzie się im fałszu czy wręcz zafałszowania, gdyż ich autor nie ma najmniejszego powodu, aby dopuścić się bodaj jednego takiego fałszu czy zafałszowania $^{62}$.

W literaturę immanentnie wpisana jest intencja kontaktu, w opowieściach autobiograficznych uwydatniony zostaje natomiast aspekt bezwstydnego odsłaniania się w obecności innych. Choć literatura kreować może przestrzeń międzyludzkiego porozumienia, to trudno oprzeć się wrażeniu, że Bernharda dyskurs o bólu kształtuje się poprzez otwarcie wrogą, świadomie niepoprawną postawę artystyczną - najradykalniej wyrażoną przez zwątpienie w możliwości języka:

Język jest bezużyteczny, gdy chodzi o mówienie prawdy, o oznajmianie czegoś, język pozwala piszącemu jedynie na przybliżenie, pełne zwątpienia i przez to bardzo wątpliwe przybliżenie do przedmiotu i oddaje tylko zafałszowany autentyzm, zniekształcenie [...], słowa [...] zamazują i z absolutnej prawdy czynią na papierze kłamstwo ${ }^{63}$.

Jeśli więc Bernhard rozbija język, destabilizuje syntaksę, posługuje się powtórzeniami (repetycją, z której wyłania się szczególny rytm, muzyczność jego prozy), igra z jawnym nonsensem, to łatwo wywnioskować, że jego intencją nie jest stworzenie jasnej, precyzyjnej opowieści o bólu i chorobie. By zidentyfikować celowość artystycznych wyborów Bernharda, trzeba uwydatnić rolę cudzej mowy, szczególnie istotnej w momentach nasycania, czy raczej infekowania, prywatnej narracji językiem medycyny (dominującym,

${ }^{60}$ I jednocześnie od-grywana jako prawda ,jak gdyby”. Twórczo rozwijał ów problem Marcin Polak, który stwierdzał, że dla Bernharda (jako pisarza) istotne jest nie przedstawienie prawdy, lecz odpowiednio intensywne uobecnienie jej śladu w fikcji literackiej (M. Polak, Trauma bezkresu. Nietzsche, Lacan, Bernhard i inni, Kraków 2016, s. 202).

${ }^{61}$ T. Bernhard, Oddech. Wyzwolenie..., s. 232.

${ }^{62}$ Ibidem, s. 231.

${ }^{63}$ T. Bernhard, Chłód. Izolacja..., s. 317. 
opresyjnym i wzbudzającym lęk). Lech Witkowski przekonująco uwydatnia wpisaną w Bachtinowską koncepcję cudzej mowy funkcję dystansującą ujawniającą się w napięciu związanym z niezrozumiałością, niejasnością obcego idiomu - która prowadzi do otwarcia tekstu na odmienne perspektywy, inne możliwości wyrażania siebie ${ }^{64}$. Mowa lekarzy wywoływała w bohaterze lęk, nazwy chorób wzbudzały przerażenie, toteż w ramach literackiej narracji podejmuje on próbę konfrontacji z tajemniczą, nieuchronną mocą słowa-wyroku. Intencja Bernharda sprowadza się do prób przysposobienia języka do ekspresji najbardziej podmiotowych, idiomatycznych doświadczeń, podporządkowania słów zmiennym stanom ducha, chwiejnej, niejednoznacznej emocjonalności. Można to uczynić poprzez wysunięcie na plan pierwszy elementu obcego, nie swojego, który przysłania coś rzeczywistego, intymnego:

Nie można oddać stanu mojego umysłu, nie do odtworzenia jest stan moich uczuć, wystrzegam się też posuwania dalej, niż to bezwzględnie konieczne, ponieważ dla mnie samego nie do zniesienia jest męka przekroczenia granicy w kierunku prawdy czy w ogóle prawdy na ten temat ${ }^{65}$.

Jeśli uporczywa repetycja demaskuje arbitralność i samozwrotnośćc6 języka, który okazuje się nieadekwatny wobec niepochwytnej intensywności ludzkich myśli i doznań, to jedynie poprzez destrukcję szczelnych, stabilnych, uładzonych form wyrazu (odpluwanie języka ${ }^{67}$ ) objawić się może idiom bólu jako ślad gniewu ${ }^{68}$ i podmiotowej witalności ${ }^{69}$.

W prozie Bernharda zidentyfikować można wiele punktów agresywnej konfrontacji, znaków jawnego, czasami niemal rozpaczliwego gniewu:

${ }^{64}$ L. Witkowski, Uniwersalizm pogranicza. O semiotyce kultury Michała Bachtina w kontekście edukacji, Toruń 1991, s. 61. Ryszard Nycz trafnie konkludował, iż tekst jest „przewodnikiem, który prowadzi do rozumienia innego, jeśli równocześnie pozwala, jak sugerował Bachtin, na rozumienie siebie w kategoriach innego [...]" (idem, Kultura jako czasownik. Sondowanie nowej humanistyki, Warszawa 2017, s. 174).

${ }^{65}$ T. Bernhard, Chłód. Izolacja..., s. 288.

${ }^{66}$ Michel Foucault pisał o immanentnej dla języka funkcji autoprzedstawiania. Por. idem, Język bez końca, przeł. M.P. Markowski [w:] idem, Powiedziane, napisane. Szaleństwo i literatura, oprac. T. Komendant, Warszawa 1999, s. 69.

${ }^{67}$ Odwołuję się tu do frapującej sugestii Adama Lipszyca: „Czy wpadając w te repetycje, narratorzy książek Bernharda próbują coś odpluć? Opluwają świat, ale może też ów świat odpluwają? Może odpluwają język, który puchnie im w ustach, przepełniony banałem język tego świata?” (idem, Odpluwanie światem..., s. 11).

${ }_{68}$ Jak powiada o gniewie Sloterdijk: „To afekt, który jest w stanie tworzyć jakby ciemne pojęcia ogólne i wznosić się w mgliste abstrakcje" (idem, Gniew i czas..., s. 67).

${ }^{69}$ Witalności, która objawia się w stylistyce prozy Bernharda (por. M. Kędzierski, Egocentryk w poszukiwaniu bliźniego swego. Proza Thomasa Bernharda, „Literatura na Świecie" 1991, nr 6, s. 147). 
Znienawidziłem nagle wszystko, co zdrowe. Moja nienawiść w jednej chwili skierowała się przeciw wszystkiemu poza obrębem Grafenhofu, przeciw wszystkiemu na świecie, nawet przeciw własnej rodzinie ${ }^{70}$.

Nienawidziłem nie tego, co Tutaj, lecz tego, co Tam. Po Drugiej Stronie i Na Zewnątrz wszystkiego innego! $!^{71}$.

Świat budzi przeważnie obrzydzenie, patrząc weń, patrzymy w kloakę. Czyż nie $?^{72}$.

\section{Według Petera Sloterdijka:}

Przypływ gniewu pojawia się, gdy Inni odmówią mi swojego uznania (w odpowiedzi na co powstaje gniew ekstrawersyjny), pojawia się jednak także, kiedy ja sam odmawiam sobie uznania w świetle własnych poglądów na wartości (tak że mam powód zagniewania się na siebie samego). [...] Z reguły jednak impuls tymotejski łączy się z życzeniem potwierdzenia poczucia własnej wartości w reakcji Innych ${ }^{73}$.

Niemiecki filozof w swoich analizach uwydatnia „stronę energetyczną" gniewu, który wykazuje się potencjałem ,udostępniania i przekazywania energii" 74 . W tej perspektywie gniew byłby rodzajem surowca, którego dystrybucja, czy raczej transpozycja, stanowiłaby działanie ożywcze, pobudzające. Jako że na antypodach gniewu sytuuje się entropia, to ekspresje wzburzenia/ wściekłości zyskują tu wymiar mechanizmu obronnego zwróconego przeciw acedii, radykalnej inercji, w którą popada podmiot chory. By spożytkować witalność wpisaną w gniew, konieczny jest jednak aspekt teleologiczny buntu (,Absurdalna nienawiść [niem. der absurde Haß - przyp. S.P.] stała się naraz niemożliwa"75). W prozie Bernharda przybiera on postać słusznego gniewu jako gwałtownej reakcji na niesprawiedliwość. Uzasadnione wydaje się zatem stwierdzenie, iż narrator nie tylko identyfikuje cierpienie w świecie, lecz również - w ramach specyficznej konceptualizacji gniewu - sam poniekąd nasyca ów świat doświadczanym przez siebie bólem. W Oddechu i Chłodzie dokonuje się konfrontacja z ,historiami cierpienia”, z obecnością ,niesamowitego bólu, wykraczającego poza pojęcia bólu"76. I jeśli nie sposób poskromić intensywności doznania siłą własnej woli, to - w rozpaczliwym geście ocalenia siebie - chory z otchłani bólu zdobyć się może, poprzez kumulację gniewu,

\footnotetext{
${ }^{70}$ T. Bernhard, Chłód. Izolacja..., s. 277.

${ }^{71}$ Ibidem, s. 281.

72 Ibidem, s. 305.

73 P. Sloterdijk, Gniew i czas..., s. 32.

${ }^{74}$ Ibidem, s. 65.

75 T. Bernhard, Chłód. Izolacja..., s. 282.

${ }^{76}$ Ibidem, s. 328.
} 
na gwałtowną ekspresję idiomatycznej obecności w ramach agonu; na mocną indywidualną replikę, która byłaby ,intensywnym zwrotem ku adresatowi”77 (przywracającym cierpiącemu jego godność ${ }^{78}$.

\section{Bibliografia}

Bernhard T., Chłód. Izolacja [w:] idem, Autobiografie, przeł. S. Lisiecka, Wołowiec 2011, s. 269-350.

Bernhard T., Oddech. Wyzwolenie [w:] idem, Autobiografie, przeł. S. Lisiecka, Wołowiec 2011, s. 189-267.

Cioran E., Brewiarz zwyciężonych, przeł. I. Kania, Kraków 2016.

Cioran E., O niedogodności narodzin, przeł. I. Kania, Warszawa 2008.

Cioran E., Zeszyty 1957-1972, przeł. I. Kania, Warszawa 2016.

Foucault M., Inne przestrzenie, przeł. A. Rejniak-Majewska, „Teksty Drugie” 2005, nr 6, s. 117-125.

Foucault M., Język bez końca, przeł. M.P. Markowski [w:] idem, Powiedziane, napisane. Szaleństwo i literatura, oprac. T. Komendant, Warszawa 1999, s. 67-79.

Foucault M., Narodziny kliniki, przeł. P. Pieniążek, Warszawa 1999.

Jasnowski P., Świat jako kloaka i udawanie sensu. Paliatywy w świecie prozy Thomasa Bernharda, „Teksty Drugie” 2017, nr 2, s. 375-398.

Jünger E., O bólu, przeł. J. Prokopiuk, „Literatura na Świecie” 1986, nr 9, s. 177-230.

Kędzierski M., Egocentryk w poszukiwaniu bliźniego swego. Proza Thomasa Bernhar$d a$, „Literatura na Świecie” 1991, nr 6, s. 116-148.

Kopaliński W., Perwersja [w:] Słownik wyrazów obcych i zwrotów obcojęzycznych, Warszawa 2007, s. 438.

Kristeva J., Potęga obrzydzenia. Esej o wstręcie, przeł. M. Falski, Kraków 2007.

Lipszyc A., Odpluwanie światem, „Książki w Tygodniku. Dodatek do »Tygodnika Powszechnego《" 2011, nr 5, s. 9-11.

Lipszyc A., W tył zwrot na Reichenhallerstrasse, „Literatura na Świecie” 2012, nr 7-8, s. 412-427.

Mackiewicz W., Ciało i polityczność. Koncepcja cielesności w filozofii Michela Foucaulta, Kraków 2018.

Morris D.B., The Culture of Pain, Berkeley 1993.

Nycz R., Kultura jako czasownik. Sondowanie nowej humanistyki, Warszawa 2017.

77 P. Sloterdijk, Gniew i czas..., s. 67.

78 Nawiązuję tu do ikonografii cierpienia, która - jak przypomina Susan Sontag - upodobała sobie przedstawienia, w których ból i gniew stają się warunkiem godnego cierpienia: „Cierpienia uznawane za godne przedstawienia to najczęściej te postrzegane jako skutek gniewu” (S. Sontag, Widok cudzego cierpienia, przeł. S. Magala, Kraków 2010, s. 51). 
Orygenes, Komentarz do Listu św. Pawła do Rzymian, przeł. i oprac. S. Kalinkowski, wstęp E. Stanula, Warszawa 1993.

Polak M., Trauma bezkresu. Nietzsche, Lacan, Bernhard i inni, Kraków 2016.

Sendyka R., Od kultury ja do kultury siebie. O zwrotnych formach $w$ projektach tożsamościowych, Kraków 2015.

Sloterdijk P., Gniew i czas. Esej polityczno-psychologiczny, przeł. A. Żychliński, Warszawa 2011.

Sloterdijk P., Krytyka cynicznego rozumu, przeł. P. Dehnel, Wrocław 2008.

Sontag S., Choroba jako metafora. AIDS i jego metafory, przeł. J. Anders, Warszawa 1999.

Sontag S., Widok cudzego cierpienia, przeł. S. Magala, Kraków 2010.

Welsch W., Estetyka i anestetyka, przeł. M. Łukasiewicz [w:] Postmodernizm. Antologia przekładów, red. R. Nycz, Kraków 1998, s. 520-547.

Witkowski L., Uniwersalizm pogranicza. O semiotyce kultury Michała Bachtina w kontekście edukacji, Toruń 1991.

Wittchen-Barełkowska A., Kategoria teatralności w dziele Thomasa Bernharda, Poznań 2014. 